\title{
Assessing the penetration of bioethanol in the andean community: a review
}

\section{Evaluación de la penetración del bioetanol en la comunidad andina: una revisión}

*ANA BELÉN GUERREROa,b, MARÍA DOLORES CURT ${ }^{a}$

aDepartamento de Producción Agraria, Universidad Politécnica de Madrid (UPM). Madrid, Spain

bDepartamento de Sostenibilidad. Trisquel Consulting Group. Quito, Ecuador

*ana.guerrero@trisquel.ec

\section{ABSTRACT}

The sustainable development agenda of the United Nations aims to ensure affordable energy for all and to diminish greenhouse gas emissions in order to mitigate the effects of climate change. A way to achieve these goals is by the substitution of fossil fuels with biofuels. This study compares three Andean countries: Colombia, Ecuador and Peru, in terms of bioethanol blending mandates current scenario and its sustainability. For this analysis, a review of the state of the art of first and second generation bioethanol in the three countries were developed, including a social network analysis to understand the interactions that have enhanced or delayed the achievement of their blending objectives as countries. So far, Colombia is near to reach its blending target; Ecuador has recorded a bioethanol deficit, estimated at $75 \%$; and regarding Peru, in the last years they have achieved their national target. In addition to blending mandates, the countries appear not to rely on a sustainability policy for the development of first or second generation bioethanol. Furthermore, these Andean countries are planning to increase their blending targets. In order to achieve this, political efforts must be focused on feedstock availability as well as on the development of guidelines related to sustainability and technologies to be applied in their own context.

Keywords:

Policy, Latin America, sustainable development, first and second generation ethanol.

\section{INTRODUCTION}

Climate change is the most economically and politically complex problem that humanity is currently facing (Sachs, 2015). For this reason, climate change is at the top of the sustainable agenda, and minimizing its impact on the environment has turned as a priority in the post 2015 development agenda, where developing countries are expected to play an increasing role in global climate change mitigation.

In 2015, the United Nations (UN) proved that the global emissions of carbon dioxide (CO2) continued their upward trend (United 
Nations, 2015). In fact, on a global average basis, historical levels of $\mathrm{CO} 2$ were reached in this year (400 ppm for the first time) (WMO, 2016). Hence, the UN established the seventh goal of the Sustainable Development Goals (SDG) in the post 2015 agenda -which aim is "to ensure access to affordable, reliable, sustainable and modern energy for all" - for which countries have to bet for renewables to diminish climate change impact, but countries commitment is needed. In fact, since the Conference of the Parties (COP21), 175 out of 197 parties have ratified the Paris Agreement. The central aim of the agreement is to strengthen the global response to the threat of climate change by keeping a global temperature below $2{ }^{\circ} \mathrm{C}$ above pre-industrial levels (UNFCCC, 2018).

Facing the problems derived from climate change and the increasing scarcity of petroleum resources, many nations are turning to renewable energy. There is a wide range of renewable technologies (bioenergy, solar, wind, geothermal and others) that can be used depending on the availability of natural resources in each country, but biomass receives priority because it is the single largest renewable energy source that can be directly used for production of biofuels (Dwivedi, Alavalapati, \& Lal, 2009; IEA, 2015).

Considering energy as an indispensable component of society, and transportation the activity that demands the largest share of final energy in the world (Ballesteros, 2010a), which implies half of the world oil consumption and a fifth of its greenhouse gas (GHG) emissions (IRENA, 2016), the scientific community and global leaders priority and promoting research on renewables in order to improve the wellbeing of the society (Figure 1).

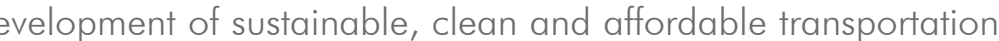
in order to achieve the SDG (B. Solomon \& Bailis, 2014). It means that governments must play a hinge role, making societal needs a

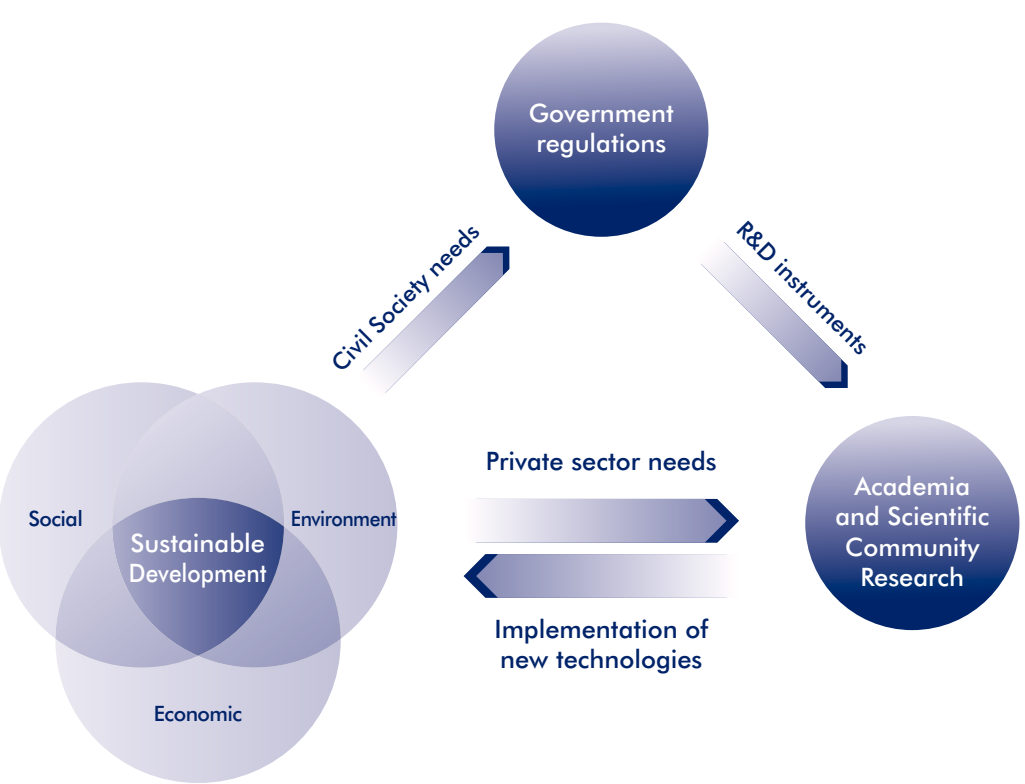

Figure 1. Relation and role of the government, scientific community and civil society to achieve a sustainable development.

Liquid biofuels can contribute to guarantee energy security and diminish the current fossil fuel dependence. In addition, biofuels have the potential to improve air quality and mitigate global warming on the grounds of a reduction in GHG emissions. Furthermore, biofuel production can provide new income and employment opportunities in urban and rural areas. Indeed, in a global overview developed by the Renewable Energy Policy Network for the 21 st Century (REN21), in 2015 liquid biofuels were positioned as the second largest employer in the renewables area with 1.6 million jobs (REN21, 2016).

Biodiesel and bioethanol are the main liquid biofuels in the market. This study focuses on bioethanol since it is the most widely used biofuel worldwide (Ballesteros, 2010b). There is no generic 
agreement for international standard classification of bioethanol; however, three main categories of biofuels are usually recognized: (i) First generation (1G), which is produced mainly from foodbased feedstock or staple crops of high saccharide content like sugarcane, maize and wheat, and has already reached a commercial stage. (ii) Second generation (2G), which is produced from nonedible biomass or lignocellulosic plant materials, like forestry and agricultural residues and municipal solid wastes, and involves cheap and abundant feedstock (Naik, Goud, Rout, \& Dalai, 2010), but an intermediate technology is needed for its biochemical or thermochemical conversion (Strezov, 2014). Lignocellulosic biomass has gained attention as being a potential low-cost feedstock that avoids competition with food demand, especially the use of forest and agricultural residues (Takara, Shrestha, \& Khanal, 2010). (iii) Third generation (3G) ethanol, currently in laboratory experimentation with the use of algae and genetically modified organisms (Strezov, 2014).

Nowadays, Brazil and the United States have a well-established IG bioethanol industries, and lead the ethanol production of the world representing $30 \%$ and $57 \%$, respectively, of the worldwide production (98.3 billion liters) (REN21, 2016). US uses as main feedstock maize and Brazil sugarcane. However, concerns about the sustainability of this type of biofuel, which is based on edible crops as feedstock, have been raised (B. D. Solomon, Baneriee, Acevedo, Halvorsen, \& Eastmond, 2014) due to a possible food vs. fuel market competition, direct and indirect land-use changes, and biodiversity loss.

Some developing countries are also interested in bioethanol production to encourage rural development, diminish fossil fuel importations and diminish GHG emissions in furtherance of the SDG compliance. According to Pistonesi et al. (2008) the production of biofuels in Latin America could be seen as a strategy to achieve agricultural, environmental and energy development. Specifically, South America is considered as a territory that has large renewable energy resources, which could contribute to the coverage of the world's

energy demands (Janssen \& Rutz, 2011).

The purpose of this article is to review the state of the art of $1 G$ bioethanol production in three countries of the Andean Community: Colombia, Ecuador and Peru, compare the regulations established to promote bioethanol production, and determine if these countries have tools to ensure the sustainable development of biofuels. These three countries were chosen because they are neighboring countries, possess extensive land areas with similar climate conditions, and in consequence cultivate similar crops and produce similar agricultural residues. Additionally, they exhibit different stages of maturity of their political agenda regarding biofuels. To the best of our knowledge, developing countries that have demonstrated interest in biofuels in the last decade have been barely considered in research or report works, but an indepth study is needed to understand the implications of the success or delay of the progress of biofuels in these countries.

\section{METHODS}

\section{Collection of information}

To analyze blending mandates and legal framework that leads the development of the bioethanol industry in the countries under study, all the legal instruments related to biofuels were studied and are listed in Table 1. An analysis of sustainability instruments used in each country to ensure the sustained development of bioethanol in the social, environmental and economic aspects was developed. This includes policies analyses that reinforce the government duty in each legal framework, and the study of some multilateral reports. 


\section{Social Network Analysis}

The legal framework related to the enhancement of biofuels in the three countries was analyzed and the main actors were detected (listed below), including the responsibilities and duties that the law assigned. Then, a social network analysis was developed using UCINET 6 and NetDraw software (Analytic Technologies, US) following the methodology described in (Moncayo Miño \& Yagüe Blanco, 2016). Social network analysis allows creating a network map on interaction among stakeholders of a sector (Vantoch-Wood \& Connor, 2013). It provides a way of making tangible some areas where the political will has incidence and its interactions. In addition, some effects can be studied like communication network structure (Borgatti, Mahra, Brass, \& Labianca, 2009), network weakness, gaps and patterns (Vantoch-Wood \& Connor, 2013). Network research has been widely used in a great number of fields, including social sciences, physics and biology. In addition, several applied fields use this tool such as governance (Bonvecchi, Johannsen, Morales, \& Scartascini, 2015; Borg, Toikka, \& Primmer, 2015), public policy (Ingold, 2014) and natural resources (Bodin \& Crona, 2009).

For the analysis, six different areas of incidence of the law were considered: social, economic, environmental, research \& development $(R \& D)$, productive and regulatory. These areas were considered for the analysis because they are prioritized by the laws analyzed in Table 1, and they are under the umbrella of biofuels purposes and its sustainable development. Betweenness centrality was selected as the analyzed variable. This measure represents the number of times that a node is in the way of two nodes that are not related (Wasserman \& Faust, 1994). However, the approach for a network analysis on selected laws and the visualization of connection between areas of incidence is a procedure rooted in mathematical and physical domains of network theory (Newman, 2003).

Table 1

Legal framework related to the enhance of bioethanol industry and blending mandates

ل)

\begin{tabular}{|c|c|c|c|}
\hline Year & Colombia & Ecuador & Peru \\
\hline 2001 & Law 693 & - & - \\
\hline 2002 & Law 788 & - & - \\
\hline 2003 & Resolution 180687 & - & Law 28054 \\
\hline 2004 & Law 939 & - & - \\
\hline 2005 & - & - & Supreme Decree 013 \\
\hline 2006 & - & - & Resolution 400 \\
\hline 2007 & Decree 2629 & - & $\begin{array}{l}\text { Supreme Decree } 021 \text {, } \\
\text { Resolution } 014\end{array}$ \\
\hline 2008 & CONPES 3510 & - & - \\
\hline 2009 & - & $\begin{array}{l}\text { Executive Decree 1831, Executive } \\
\text { Decree } 1879\end{array}$ & $\begin{array}{l}\text { Supreme Decree } 091, \\
\text { Resolution 206, } \\
\text { Resolution } 515\end{array}$ \\
\hline 2010 & - & Organic Law of Food Sovereignty & Supreme Decree 061 \\
\hline 2011 & Decree 4892 & Executive Decree 971 & Supreme Decree 024 \\
\hline 2013 & Resolution 90932 & Executive Decree 1048 & - \\
\hline 2015 & Resolution 41072 & $\begin{array}{l}\text { Executive Decree 799, } \\
\text { Executive Decree 675, } \\
\text { Resolution 031 }\end{array}$ & - \\
\hline 2016 & Resolution 789 & - & - \\
\hline
\end{tabular}


In the Colombian case, 11 main actors were identified: Ministry of Mines and Energy (MME), Ministry of Agriculture and Rural Development (MADR), Ministry of Transportation (MT), Ministry of Environment and Sustainable Development (MADS), National Planning Department (DNP), Ministry of Finance and Public Credit (MHCP), Ministry of Commerce, Industry and Tourism (MCIT), Administrative Department of Science, Technology and Innovation (COLCIENCIAS), Ministry of Health and Social Protection (MSPS), Banking Superintendence (SB), and Superintendence of Ports and Transports (SPT).

For Ecuador, nine actors were considered as key players for the development of biofuels according to the law: the Central Government (CG), Ministry of Agriculture, Livestock, Aquaculture and Fisheries (MAGAP), Coordinating Ministry of Production, Employment and Competitiveness (MCPEC), Ecuadorian Standardization Service (INEN), Public Company of Hydrocarbons of Ecuador (EP PETROECUADOR), Regulatory and Control Agency Of Hydrocarbons (ARCH), National Institute of Energy Efficiency and Renewable Energies (INER), National Customs Service of Ecuador (SENAE), and Coordinating Ministry of Strategic Sectors (MICSE). It is important to highlight that since 2017, some of these institutions have disappeared due to the change of government and certain competences have not yet been granted to other institutions.

Finally, in the Peruvian case, 12 institutions were recognized as main actors related to the development and enhancement of biofuels intended for ground transport: National Commission for Development and Life without Drugs (DEVIDA), Agency for the Promotion of Private Investment (PROINVERSION), Ministry of Energy and Mines (MINEM), National Environment Council (CONAM), Petróleos del Perú (PETROPERÚ), Ministry of Economy and Finance (MEF), Supervisory Body of Investment in Energy and Mining (OSINERGMIN), Ministry of Production (PRODUCE), Ministry of Agriculture and Irrigation (MINAG), National Council of Science, Technology and Technological Innovation (CONCYTEC), Selva y Sierra Exportadora (S\&S Exportadora), National Institute for the Defense of Competition and Protection of Intellectual Property (INDECOPI).

\section{RESULTS AND DISCUSSION}

\section{Biofuel targets and blending mandates}

Biofuel blending mandates are one of the most common policies used in the transportation sector that enhance the use of renewable energy (UNCTAD, 2016). Government policies have played a major role in the development and expansion of the biofuel industry globally over the last decades. In this sense, some countries from Latin America have developed policies to promote biofuels production based on successful experiences like in the US and Brazil (Pérez-Peña \& Acharya, 2015).

Biofuel mandates and targets have been established in 66 countries, of which 19 are in the Americas, including the countries under study: Colombia, Ecuador and Peru (Lane, 2018; Maltsoglou, Koizumi, \& Felix, 2013).

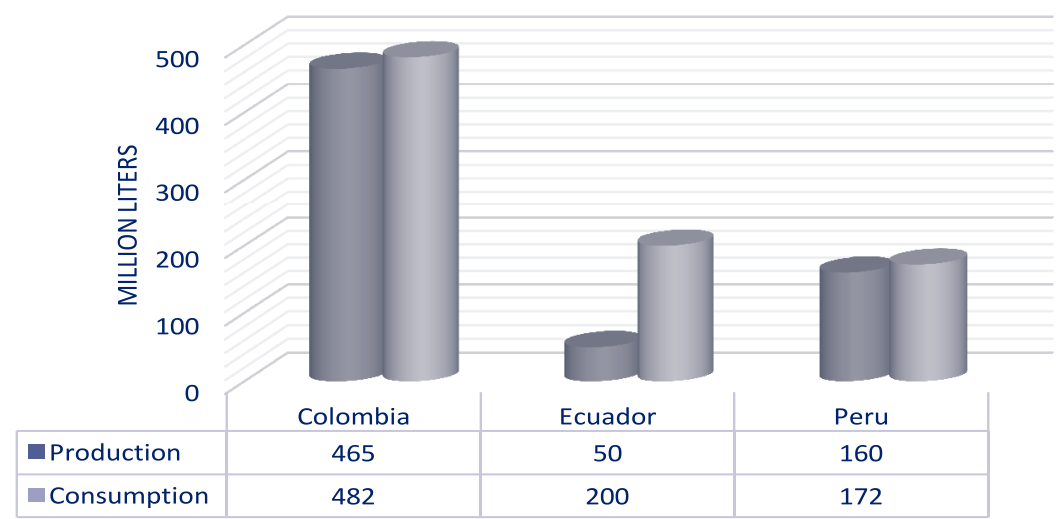

Source: Colombia 2016 (USDA, 2016), Ecuador 2016 (Ministerio de Producción, 2016), and Peru 2015 (OECD/FAO, 2014).

Figure 2. Relation between production and consumption of bioethanol in Colombia, Ecuador and Peru. 


\section{Colombia}

Colombia has emerged as one of the largest producers of biofuels in Latin America, and currently is producing both oil palm biodiesel and sugarcane bioethanol. The bioethanol mandate stipulates a national use of E8 and E10 (10\% anhydrous ethanol and $90 \%$ gasoline) for ground transportation depending on the region (Global Renewable Fuels Alliance, 2015).

The blending mandate is accompanied by tax incentives for selling bioethanol and importing machinery. Ethanol prices are fixed by the government based on a monthly calculated price, where a parity price for international sugar prices is applied (USDA, 2016). Despite the establishment of legal instruments to encourage the development of the biofuels industry, Colombia has not covered its national demand (see Figure 2), and ethanol from other countries is imported.

Figure 3a shows that the efforts to promote the use of biofuels in Colombia are focused on the economic area, where more actors are involved and more actions have been devoted. Moreover, the network shows that the Ministry of Mines and Energy (MME) and the Ministry of Agriculture and Rural Development (MADR) are the key players because they share responsibilities in more areas of incidence than other actors, being their centrality measures higher than the others are. Indeed, the network analysis shows a centralized structure in a form of star, which is considered as the fastest performing network (Borgatti et al., 2009). The net shows connection between their actors, including five of the six areas studied. In consequence, their joint efforts allow the development of biofuels in the country, but the social aspect must be improved. The implementation of biofuel laws requires a holistic approach in order to ensure its sustainability.

Although Colombia is near to achieve their blending target, ethanol producers seem not to have security to continue investing.
Indeed, there was the need to seek government protection because of high ethanol imports from the United States, which hit record levels in 2013 due to the preferences granted in the Trade Promotion Agreement set between both countries. In 2014, the Colombian government had to restrict ethanol imports, only allowing when the domestic supplies run out of anhydrous ethanol for its blending mandate fulfillment (USDA, 2016).

Colombia shows a trend to a gradual increase of biofuels aiming at the partial substitution of fossil fuels and reduction on importation of energy (Cremonez et al., 2015). Indeed, the government aims to increase ethanol blends up to 25\% by 2020 (Sorda, Banse, \& Kemfert, 2010), but according to our approach, there is no public policy that ensures this. Colombia's ethanol supply is safeguarded due to the possibility of imports in the case of the lack of ethanol in the country, but the private industry has no security on their long-term production due to the government's lack of clarity on the issue that blending mandates will increase over time.

It is worth mentioning that Colombia clearly presents a more developed industry in the private sector, which has already reach the organizational stage of association named "Fedebiocombustibles", since 2004. This association has become an active actor in the promotion and strengthening in biofuels projects.

\section{Ecuador}

Ecuador's Constitution encourages the development of renewable energy sources. In 2004 the government declared biofuels as a "national interest" by executive decree, but there was a lack of specific legislation and regulations for biofuels development and production (USDA, 2012) and later that decree was repealed. After this, it was not until 2010 that the country started activities related to biofuels. A pilot 
program named Ecopais started in that year, which main aim was to test the consumer acceptance of an E5 gasoline. During the time of the pilot program, the government regulated the price of ethanol at USD $0.76 / L$, and such program gave purchase priority to artisanal ethanol producers. However, since May 2015, the price has been set according to the Argus US Gulf Coast ethanol price, and the government ensured that the price payed to the producers could not be less than USD 0.90/L (bottom band)

The pilot program was a success, so in 2014 the government stablished the mandate to achieve the full replacement of common gasoline with E5 blended gasoline in 2017, followed by full E10 blend in 2018. However, this target is a challenge because the production in 2015, which was entirely from sugarcane, only covered $25 \%$ of the national demand, as it is shown in Figure 2, and until December 2017, E5 blended gasoline was distributed in eight of the 24 provinces of Ecuador (EPPetroecuador, 2017). This fact demonstrates that the national mandate was very ambitious in quantity and time of execution. Though some efforts have been done, it have not been enough considering that during 2017 some of the institutions responsible for the execution were suppressed, causing instability in the ethanol production.

Figure $3 b$ clearly shows many structural holes in the network because it illustrates an open binding mechanism, and it is the network with more excluded nodes demonstrating weakness. In fact, the network shows disconnection in three of the six studied areas. When a network present many structural holes demonstrate disconnection between actors. This effect could be one explanation of the delay observed in Ecuador compared to its neighboring countries. In addition, the net shows that the efforts of the government, in legal matter, were directed towards strengthening the productive and economic areas, since the main objective of the ecopais program was to decrease imports of high-octane naphtha used in the preparation of common gasoline.

Considering that biofuels by concept are intended to reduce GHG emissions in order to mitigate the effects of climate change, no law has considered the Ministry of Environment as an actor, to make sure that the development of biofuels in the country is supported with environmental criteria. Moreover, as key player stands out the Coordinating Ministry of Production, Employment and Competitiveness, to whom all the competences related to biofuels were transferred and centralized. This is a major weakness because if this actor does not accomplish its duties, recognized by the law, the interconnection between regulatory, economic and productive areas could fail. Nowadays, this ministry does not exist.

Ecuador has a clear potential to establish a biofuel industry because of its existing biomass resources, geographical advantages, and its high level of interest. In addition, the country is clearly aware that the food vs. fuel competition has to be avoided. Ecuador is one of the seven countries of Latin America that prioritize food security over biofuels (Bailis, Solomon, Moser, \& Hildebrandt, 2014). In fact, the Organic Law of Food Sovereignty (2010) states the prioritization of food production "as long as possible" over biofuels production (IRENA, 2015). Thus, Ecuador should search for more or new feedstock for bioethanol production because the country is highly dedicated to agriculture and agroindustry $(9.4 \%$ of the gross domestic product GDP) (The World Bank, 2014).

To achieve Ecuador's mandate while the bioethanol industry turns auto-sustainable, the government must start granting the competences of the disappeared MCPEC to another institution that is able to create and enhance alliances among the productive sector of biomass, processing industry, retailers and oil companies. 
General challenges comprise the mismatch between bioethanol processing capacities and the feedstock supply sector, and/or the risk of insufficient raw material. Thus, a milestone that must be included in the political agenda is to reach the installed bioethanol processing capacity (Maltsoglou et al., 2013). The achievement of the mandates must go hand in hand with careful planning in order to avoid the dependence of biofuel importation.

\section{Peru}

In 2003, the country adopted policies to enhance biofuel production. Afterwards, in 2007 the government established target E7.8, which is obligatory in a national scale since 2010 (Cremonez et al., 2015). The blending mandate was expected to contribute to energy security, encourage investments, promote rural and socioeconomic development, diversify the agricultural sector, create employment opportunities and protect the environment. Peruvian policy makers explicitly stipulated the objective of biofuel production as an alternative to the illicit cultivation of coca leaves contributing to the National Strategy to Combat Drugs (B. Solomon \& Bailis, 2014).

Since 2011 , Peru has accomplished its blending target with a whole production of bioethanol from sugarcane (USDA, 2015), but in 2015 the country struggled to cover the national demand (see Figure 2) because of the closure of the main ethanol plants. Peru is one of the smaller producers of biofuels in Latin America and the Caribbean, and its production is mostly from sugarcane, but the government is also considering promoting the use of molasses. (B. Solomon \& Bailis, 2014).

Peru reached its bioethanol autonomy in a relatively short period since the country is committed to fulfilling its blending targets. Figure $3 \mathrm{c}$ shows that Peru has devoted its efforts to work articulately. This network demonstrates many interactions and high political will. It means that actors require coordination mechanisms in order to achieve a fluently acting. The government has been enhancing the productive and R\&D areas of biofuels, but the environmental incidence must be improved. Although the Ministry of Environment (CONAM) is considered as an actor in the normativity, no environmental regulations have been devoted to ensure the environmental sustainability of bioethanol. The key players are the Ministry of Energy and Mines, and PETROPERÚ, which is interesting because in this way Peru benefited of the installed capacity of the main institutions related with oil in order to make a smooth transition to this new business turnaround, benefiting of the know how that they already had about hydrocarbons.

As discussed, the three countries have political will and blending mandates, but each country has a different bioethanol industry development level. Colombia and Peru demonstrated interest for biofuels at the beginning of the 2000s and seventeen years later, they are near to achieve or have already achieved their national blending targets. This fact is also reflected in the betweenness centrality (Table 2) where Colombia and Peru have more incidence areas with values $>0$. Betweenness centrality takes value 0 when an incidence area has interaction with one actor or no interaction, and 1 when a node interacts with all the actors of the net. Meanwhile, Ecuador is delayed in the achievement of its national mandates and it could be considered that is at an early stage. Precisely for this reason, this network does not present the same maturity as the other two countries. It means that its betweenness centrality (Table 2) is 0 in four of the six areas and could be motivated by the recent interest in biofuels of the country. In addition, Colombia and Peru exhibit laws that enhance and sustain biofuels, and Ecuador has executive decrees, which turns biofuels in a vulnerable initiative to future political changes such as the close of some ministries as it has been reported previously. The three countries have one area of incidence that have not considered in their legal frameworks. In Colombia, the social incidence needs to be strengthened, and in Ecuador and Peru, 
the environmental area needs to be considered in order to ensure the environmental sustainability of bioethanol production.

a)· Social

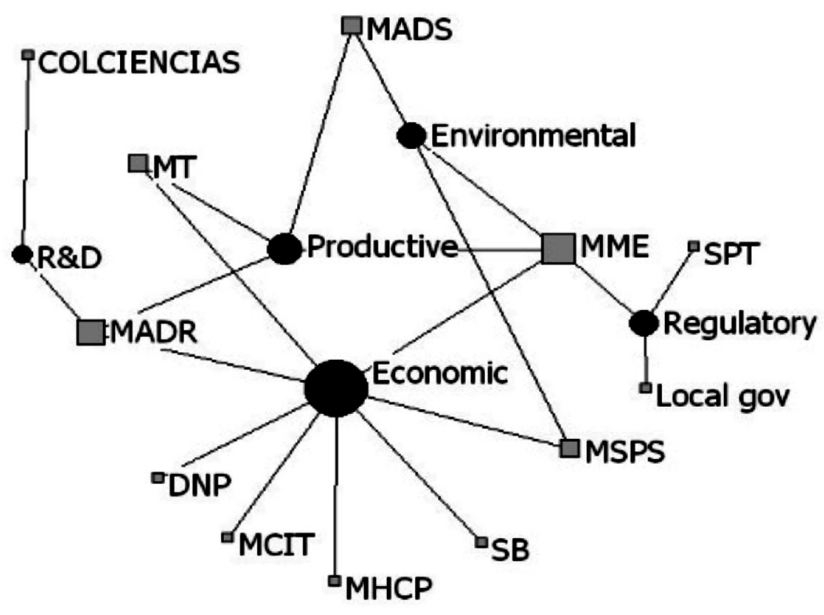

b) Environmental

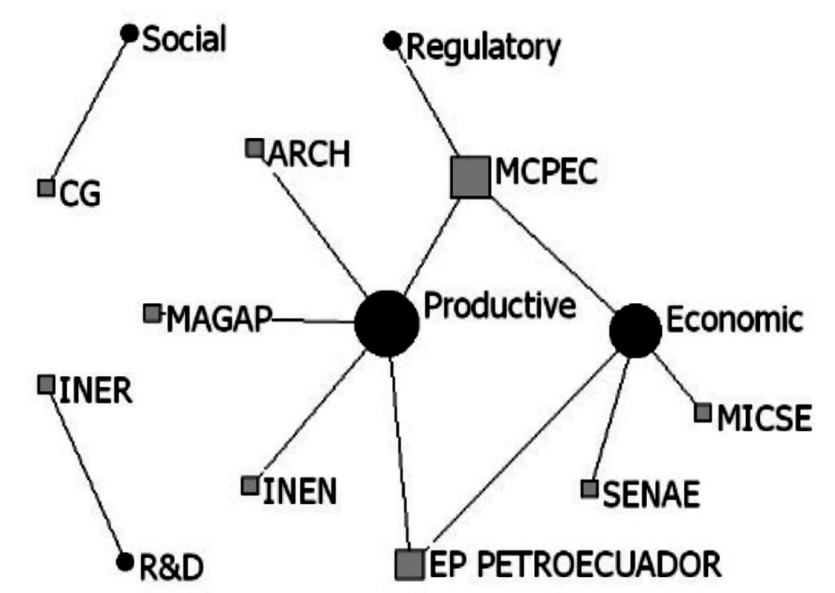

c) Environmental

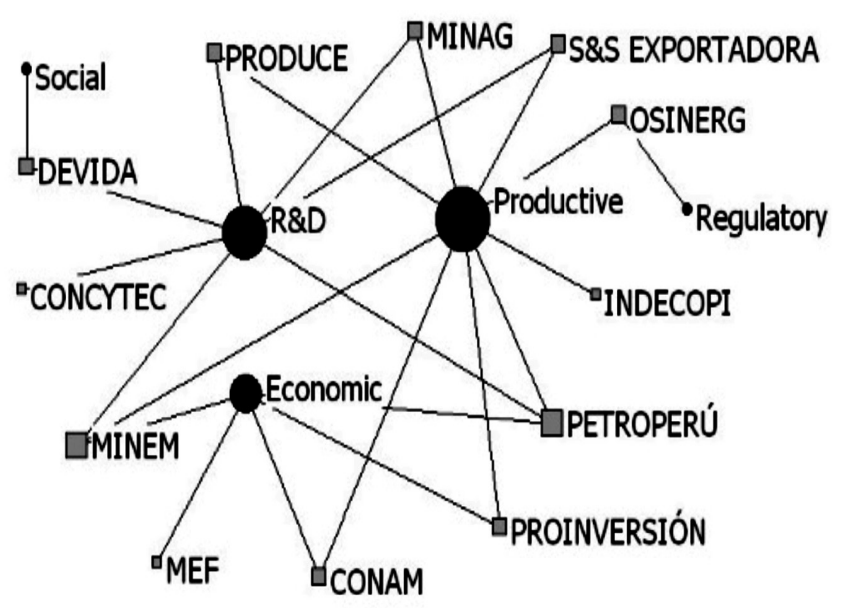

Figure 3. Social network analysis a) Colombia, b) Ecuador, and c) Peru. Circular nodes represent incidence areas, and square nodes represent actors identified in the laws. Each relation between actors and areas is represented by a line. The size of the nodes differ according to the betweenness centrality.

\section{Table 2}

Betweenes centrality in the incidence areas studied in Colombia, Ecuador and Peru. Data normalized.

\begin{tabular}{|l|c|c|c|}
\hline & Colombia & Ecuador & Peru \\
\hline Environmental & 0.06 & 0.00 & 0.00 \\
Social & 0.00 & 0.00 & 0.00 \\
Economic & 0.55 & 0.19 & 0.15 \\
Productive & 0.16 & 0.26 & 0.49 \\
i+D & 0.11 & 0.00 & 0.37 \\
Regulatory & 0.22 & 0.00 & 0.00
\end{tabular}




\section{Sustainability}

Bioethanol production has benefits and impacts on social, economic and environmental areas that vary from country to country because each one has different feedstocks, yields, transformation technologies and level of development that better suit to each national context. It is a mistake to judge biofuels in a generic way because the possibilities to shift to biofuels and the objectives to be achieved are different in each country, including the political will (Escobar et al., 2009).

One of the advantages of bioethanol lies in its local production, which is translated into a reduction of GHG emissions in feedstock transportation, the maintenance of rural life and its economic development. In fact, Brazil is a successful case in covering these three aspects. Since the 1970s, sugarcane ethanol industry in Brazil has reinvigorated $10 \%$ of Brazilian population from poverty (Nanda, Azargohar, Dalai, \& Kozinski, 2015). Moreover, Brazil overcame the necessity of subsidies for that sector and now it is economically sustainable. Indeed, foreign investors are increasing rapidly in the country due to the extraordinary capacity of ethanol production, which has been reflected in the increase of job opportunities (Hira \& de Oliveira, 2009)

Considering the fundamentals of biofuels and its dependency to a country context, sustainability has to be addressed by each government, developing policies that guarantee the three dimensions of sustainability.

section, Colombia, Ecuador and Peru have not considered one of the three areas of sustainability in their legal framework. Some multilateral biofuel certification systems for sustainability, and technical instruments developed by non-governmental organizations (B. D. Solomon et al.,
2014) could be implemented in these countries in order to ensure the sustainability of bioethanol.

On an international level, the Global Bioenergy Partnership (GBEP) coordinated an agreement on a list of 24 sustainability indicators to guide national efforts in bioenergy sector development. These indicators are voluntary and cover socioeconomic and environmental sustainability (B. Solomon \& Bailis, 2014). Colombia was chosen as the Latin American country to pilot test the GBEP sustainability indicators, and counts with a study developed with life cycle assessment approach devoted to ensure the environmental sustainability of biofuels (Consorcio CUE, 2012).

The 24 indicators by GBEP can serve to guide the countries to develop their own indicators focusing on the base line to determine the objectives that must be achieved. These should be developed with technical and scientific criteria and be based on the opinion of stakeholders, in order to decrease the gap between science and policies and to support a reflection on the decision-making process (Gomes, Malheiros, Fernandes, \& Maria, 2015). Some studies that analyzed the environmental and social effects of biofuels in developing countries recognize that biofuels sustainability depends on natural conditions, socio-economic setting and feedstock production systems, which implies that the impact of biofuels may vary from country to country (van Eijck, Batidzirai, \& Faaii, 2014).

The challenge of improving the feedstock supply through yield improvement and feedstock diversity in more sustainable ways can be accomplished, but only with prolonged support and sensible, easily adoptable policies that recognize the environmental as well as the economic objectives (UNCTAD, 2016). Deciding on energy future is not only a matter of responsibility of technology developers, funders and users; the most important responsibility falls in the political commitment 
to more participatory, comprehensive and transparent practices in the appraisal of technological change (Ribeiro \& Quintanilla, 2015). More investments in R\&D programs are required so that technologies for biofuel production could fit the needs of the countries (Escobar et al., 2009).

\section{CONCLUSIONS}

The three countries studied have bioethanol blending mandates. Colombia has not reached its blending target falling short by $3.5 \%$; Ecuador has recorded a large bioethanol deficit, estimated at 75\% for 2016, whereas Peru has already achieved its national target.

Research and innovation on new conversion technologies, feedstocks and economics of liquid biofuels are available in the studied countries, but governments have an obligation to use all possible instruments to promote R\&D with public funds to enhance the development of biofuels technology.

To ensure bioethanol industry development and sustainability, biofuel policy must be based on an exhaustive analysis of the country's context, including food security, feedstocks and bioenergy potential. The technology is there, but a supportive legislation with a clear mandate is necessary. It will be a challenge for policy makers and industry executives to improve the continued expansion of the biofuel sector, using available tools and to develop new ones in order to ensure its sustainability.

Concerning the network approach used in this study, it is important to highlight that in some cases what is stated in the law is different to what is actually happening in reality. Nevertheless, this review could provide direction for decision makers and scientific community towards relegated topics and stimulate greater integration of the network.

\section{ACKNOWLEDGEMENTS}

A. B. Guerrero gratefully acknowledges the Secretaría Nacional de Educación Superior, Ciencia, Tecnología e Innovación - SENESCYT of Ecuador for the study grant. The authors acknowledge Marco Moncayo Miño for his help in the social network analysis and Julio Escobar for the proofreading.

\section{REFERENCES}

Bailis, R., Solomon, B. D., Moser, C., \& Hildebrandt, T. (2014). Biofuel sustainability in Latin America and the Caribbean - a review of recent experiences and future prospects. Biofuels, 5(5), 469-485. http://doi. org/1.1080/17597269.2014.992001

Ballesteros, M. (2010a). Introducción a los biocarburantes. In F Sebastián, D. García-Galindo, \& A. Rezeau (Eds.), Energía de la Biomasa (pp. 395-4 15). Zaragoza: Prensas Universitarias de Zaragoza.

Ballesteros, M. (2010b). Producción de bioetanol. In F. Sebastián, D. García-Galindo, \& A. Rezeau (Eds.), Energía de la Biomasa (pp. 461487). Zaragoza: Prensas Universitarias de Zaragoza.

Bodin, Ö., \& Crona, B. I. (2009). The role of social networks in natural resource governance: What relational patterns make a difference? Global Environmental Change, 19(3), 366-374. http:// doi.org/10.1016/j.gloenvcha.2009.05.002

Bonvecchi, A., Johannsen, J., Morales, N., \& Scartascini, C. (2015). ¿Quiénes deciden la política social? Economía política de programas sociales en América Latina. Retrieved April 11, 2017, from https:// publications.iadb.org/handle/11319/7065 
Borg, R., Toikka, A., \& Primmer, E. (2015). Social capital and governance: A social network analysis of forest biodiversity collaboration in Central Finland. Forest Policy and Economics, 50, 90-97. http:// doi.org/10.1016/j.forpol.2014.06.008

Borgatti, S., Mahra, A., Brass, D., \& Labianca, G. (2009). Network analysis in the social sciences. Science, 323, 892-895. http://doi. org/10.1126/science. 116582

Cavalett, O., Junqueira, T., Chagas, M., Pereira, L., \& Bonomi, A. (2015). Techno-Economic and Environmental Impacts of Biofuel Options in Brazil. In J. Shibu \& T. Bhaskar (Eds.), Biomass and Biofuels: Advanced Biorefineries for Sustainable Production and Distribution (pp. 331-340). CRC Press.

Consorcio CUE. (2012). Evaluación del ciclo de vida de la cadena de producción de biocombustibles en Colombia. Retrieved November 10, 2016, from https://www.minminas.gov.co/ documents/10180/488888/Capitulo 0 Resumen ejecutivo final. pdf/f032d 18c-205f-499b-8d59-d1 b359e- 7 c572

Cremonez, P. A., Feroldi, M., Feiden, A., Teleken, J., Gris, D., Dieter, J., ... Antonelli, J. (2015). Current scenario and prospects of use of liquid biofuels in South America. Renewable and Sustainable Energy Reviews, 43, 352-362. http://doi.org/10.1016/i. rser.2014.11.064

Dwivedi, P., Alavalapati, J. R. R., \& Lal, P. (2009). Cellulosic ethanol production in the United States: Conversion technologies, current production status, economics, and emerging developments. Energy for Sustainable Development, 13(3), 174-182. http://doi.org/10.1016/i. esd.2009.06.003
EPPetroecuador. (2017). Informe de Gestión - Rendición de Cuentas 2017. Retrieved April 10, 2018, from https://www.eppetroecuador.ec/ wp-content/uploads/downloads/2018/02/INFORME-RENDICIONDE-CUENTAS-2017-WEB.pdf.

Escobar, J. C., Lora, E. S., Venturini, O. J., Yáñez, E. E., Castillo, E. F., \& Almazan, O. (2009). Biofuels: Environment, technology and food security. Renewable and Sustainable Energy Reviews, 13(6-7), 1275 1287. http://doi.org/10.1016/i.rser.2008.08.014

Global Renewable Fuels Alliance. (2015). Global Biofuel Mandates. Retrieved May 25, 2015, from http://globalrfa.org/biofuels-map/

Gomes, P., Malheiros, T., Fernandes, V., \& Maria, do C. (2015). Environmental indicators for sustainability: a strategic analysis for the sugarcane ethanol context in Brazil. Environmental Technology, 37(1), 16-27. http://doi.org/10.1080/09593330.2015.1059490

Hira, A., \& de Oliveira, L. G. (2009). No substitute for oil? How Brazil developed its ethanol industry. Energy Policy, 37(6), 2450-2456. http://doi.org/10.1016/i.enpol.2009.02.037

IEA. (2015). Bioenergy. Retrieved February 15, 2016, from https:// www.iea.org/topics/renewables/subtopics/bioenergy/

Ingold, K. (2014). How involved are they really? A comparative network analysis of the institutional drivers of local actor inclusion. Land Use Policy, 39,376-387. http://doi.org/10.1016/j.landusepol.2014.01.013

IRENA. (2015). Renewable Energy Policy Brief: Ecuador. Retrieved November 12,2015, from http://www.irena.org/DocumentDownloads/ Publications/IRENA_RE Latin_America_Policies_2015_Country Ecuador.pdf 
IRENA. (2016). Innovation outlook. Advanced liquid biofuels. Summary for policy makers. Retrieved November 15, 2016, from http://www. irena.org/DocumentDownloads/Publications/IRENA_Innovation Outlook_Advanced Biofuels_2016 summary.pdf

Janssen, R., \& Rutz, D. D. (2011). Sustainability of biofuels in Latin America: Risks and opportunities. Energy Policy, 39(10), 5717-5725. http://doi.org/10.1016/i.enpol.2011.01.047

Lane, J. (2018). Biofuels Mandates Around the World: 2018. Retrieved April 20, 2018, from http://www.biofuelsdigest.com/ bdigest/2018/01/01/biofuels-mandates-around-the-world-2018/

Maltsoglou, I., Koizumi, T., \& Felix, E. (2013). The status of bioenergy development in developing countries. Global Food Security, 2, 104-109.

Ministerio de Producción. (2016). Informe proyecto ecopaís. Retrieved October 21, 2016, from http://www.produccion.gob.ec/wp-content/ uploads/2016/03/INFORME-PROYECTO-ECOPAÍS-01-03-16-1.pd

Moncayo Miño, M., \& Yagüe Blanco, J. L. (2016). ¿̇Quién incide en la gobernanza local en Nicaragua? El caso de los comités municipales de la soberanía y seguridad alimentaria y nutricional. Cuadernos de Desarrollo Rural, 13(77), 11-34.

Naik, S. N., Goud, V. V., Rout, P. K., \& Dalai, A. K. (2010). Production of first and second generation biofuels: A comprehensive review. Renewable and Sustainable Energy Reviews, 14, 578-597. http://doi. org/10.1016/j.rser.2009.10.003

Nanda, S., Azargohar, R., Dalai, A. K., \& Kozinski, J. A. (2015). An assessment on the sustainability of lignocellulosic biomass for biorefining. Renewable and Sustainable Energy Reviews, 50, 925-941. http://doi.org/10.1016/i.rser.2015.05.058

Newman, M. (2003). The Structure and Function of Complex Networks. SIAM Review, 45(2), 167-256. http://doi.org/10.1137/ S003614450342480

OECD/FAO. (2014). OECD-FAO Agricultural Outlook 20132022. Retrieved May 26, 2015, from https://stats.oecd.org/Index. aspx? DataSetCode $=$ HIGH_AGLINK_2013\#

Pérez-Peña, R., \& Acharya, R. N. (2015). Are Latin American and Caribbean Biofuel Policies Consistent with their Comparative Advantages? Annual Meeting at the Southern Agricultural Economics Association's.

Pistonesi, H., Nadal, G., Bravo, V., \& Bouille, D. (2008). The Contribution of Biofuels to the Sustainability of Development in Latin America and the Caribbean. Santiago: United Nations.

REN21. (2016). Renewables 2016. Global status report. Retrieved August 16, 2016, from http://www.ren21.net/wp-content/ uploads/2016/06/GSR 2016 Full Report.pdf

Ribeiro, B. E., \& Quintanilla, M. A. (2015). Transitions in biofuel technologies: An appraisal of the social impacts of cellulosic ethanol using the Delphi method. Technological Forecasting and Social Change, 92, 53-68. http://doi.org/10.1016/j. techfore.2014.11.006

Sachs, J. (2015). The Age of Sustainable Development. New York: Columbia University Press. 
Solomon, B., \& Bailis, R. (2014). Sustainable Development of Biofuels in Latin America and the Caribbean (pp. 1-21). New York: Springer. http://doi.org/10.1007/978-1-4614-9275-7

Solomon, B. D., Baneriee, A., Acevedo, A., Halvorsen, K. E., \& Eastmond, A. (2014). Policies for the Sustainable Development of Biofuels in the Pan American Region: A Review and Synthesis of Five Countries. Environmental Management, 56(6), 1276-1294. http:// doi.org/10.1007/s00267-014-0424-6

Sorda, G., Banse, M., \& Kemfert, C. (2010). An overview of biofuel policies across the world. Energy Policy, 38(11), 6977-6988. http:// doi.org/10.1016/i.enpol.2010.06.066

Strezov, V. (2014). Properties of Biomass Fuels. In V. Strezov \& T. Evans (Eds.), Biomass Processing Technologies (illustrate, pp. 26-33). CRC Press.

Takara, D., Shrestha, P., \& Khanal, S. (2010). Lignocellulosic Biomass Pretreatment. In S. Khanal, R. Surampalli, T. Zhang, B. Lamsal, R. Tyagi, \& C. Kao (Eds.), Bioenergy and Biofuel from Biowaste and Biomass (pp. 172-200). Reston: American Society of Civil Engineers.

The World Bank. (2014). Agricultura, valor agregado (\% del PIB). Retrieved November 13, 2015, from http://datos.bancomundial.org/ indicador/NV.AGR.TOTL.ZS/countries/1W? display= default

UNCTAD. (2016). Second-Generation Biofuel Markets: State of Play, Trade and Developing Country Perspectives. Retrieved March 5, 2016, from http://unctad.org/en/pages/PublicationWebflyer. aspx? publicationid $=1455$

UNFCCC. (2018). The Paris Agreement. Retrieved April 19, 2018, from http://unfccc.int/paris_agreement/items/9485.php
United Nations. (2015). Objetivos de Desarrollo del Milenio. Informe 2015. Retrieved August 3, 2015, from http://www.un.org/es/ millenniumgoals/pdf/2015/mdg-report-2015 spanish.pdf

USDA. (2012). Ecuador Biofuels Annual. Retrieved July 15, 2015, from http://gain.fas.usda.gov/Recent GAIN Publications/Biofuels Annual Quito Ecuador 6-28-2012.pdf

USDA. (2015). Peru Biofuels Annual. Retrieved November 10, 2016, from http://gain.fas.usda.gov/Recent GAIN Publications/Biofuels Annual_Lima_Peru_7-1-2014.pdf

USDA. (2016). Colombia Biofuels Annual. Retrieved November 10, 2016, from http://gain.fas.usda.gov/Recent GAIN Publications/ Biofuels Annual_Bogota_Colombia_6-26-2014.pdf

Van Eijck, J., Batidzirai, B., \& Faaii, A. (2014). Current and future economic performance of first and second generation biofuels in developing countries. Applied Energy, 135, 115-141. http://doi. org/10.1016/i.apenergy.2014.08.015

Vantoch-Wood, A., \& Connor, P. M. (2013). Using network analysis to understand public policy for wave energy. Energy Policy, 62, 676-685. http://doi.org/10.1016/j.enpol.2013.07.066

Wasserman, S., \& Faust, K. (1994). Social network analysis : methods and applications. Cambridge University Press.

WMO. (2016). Globally averaged CO2 levels reach 400 parts per million in 2015. Retrieved November 3, 2016, from http://public. wmo.int/en/media/press-release/globally-averaged-co2-levels-reach400-parts-million-2015 